\title{
Comparison Of Drag Area Estimation Using Natural Coast Down And Constant Speed Test Methods
}

\author{
Cem Baki Mr \\ cb0087@mix.wvu.edu
}

Follow this and additional works at: https://researchrepository.wvu.edu/etd

Part of the Navigation, Guidance, Control, and Dynamics Commons, and the Other Mechanical Engineering Commons

\section{Recommended Citation}

Baki, Cem Mr, "Comparison Of Drag Area Estimation Using Natural Coast Down And Constant Speed Test Methods" (2019). Graduate Theses, Dissertations, and Problem Reports. 3759.

https://researchrepository.wvu.edu/etd/3759

This Thesis is protected by copyright and/or related rights. It has been brought to you by the The Research Repository @ WVU with permission from the rights-holder(s). You are free to use this Thesis in any way that is permitted by the copyright and related rights legislation that applies to your use. For other uses you must obtain permission from the rights-holder(s) directly, unless additional rights are indicated by a Creative Commons license in the record and/ or on the work itself. This Thesis has been accepted for inclusion in WVU Graduate Theses, Dissertations, and Problem Reports collection by an authorized administrator of The Research Repository @ WVU. For more information, please contact researchrepository@mail.wvu.edu. 

METHODS

Cem Baki Mr

Follow this and additional works at: https://researchrepository.wvu.edu/etd

Part of the Navigation, Guidance, Control, and Dynamics Commons, and the Other Mechanical Engineering Commons 


\title{
COMPARISON OF DRAG AREA ESTIMATION USING NATURAL COAST DOWN AND CONSTANT SPEED TEST METHODS
}

\section{Cem Baki}

\author{
Thesis submitted to the \\ Benjamin M. Statler College of Engineering and Mineral Resources \\ at West Virginia University \\ in partial fulfillment of the requirements \\ for the degree of
}

Master of Science

In

Mechanical Engineering

\author{
Arvind Thiruvengadam Ph.D., Chair \\ Marc C. Besch, Ph.D. \\ V'yacheslav Akkerman, Ph.D. \\ Department of Mechanical and Aerospace Engineering \\ West Virginia University \\ Morgantown, West Virginia \\ 2019
}

Keywords: Coast-down, fuel consumption, constant speed test, chassis dynamometer, drag area, drag coefficient, tire rolling resistance

Copyright 2019 Cem Baki 


\begin{abstract}
COMPARISON OF DRAG AREA ESTIMATION USING NATURAL COAST DOWN AND CONSTANT SPEED TEST METHODS
\end{abstract}

\title{
Cem Baki
}

Currently in US, more than 26 percent of the total GHG emissions comes from transportation and mostly from heavy duty vehicles. Similarly, the European Council stated that 25 percent of the $\mathrm{CO}_{2}$ emissions comes from heavy duty transportation and they expect it to be further increased in the future. However, with the new coming regulations US EPA and European Council aiming to reduce the $\mathrm{CO}_{2}$ emissions by 80 percent in US and 60 percent in EU. In order to keep track and control the $\mathrm{CO}_{2}$ emissions, both authorities published new regulations and testing methods for certifying the new vehicles.

Aerodynamic testing is one of the most important part of $\mathrm{CO}_{2}$ certification since, aerodynamic drag is a major contributor of total road load acting on a vehicle which is highly related with $\mathrm{CO}_{2}$ emissions of a vehicle. Besides, simulation tools for $\mathrm{CO}_{2}$ certification such as "Vehicle Energy Consumption Calculation Tool (VECTO)" and "Greenhouse Gas Emission Model (GEM)" needs drag area $\left(C_{D} A\right)$ as an input. Moreover, it is essential to determine the drag 
area correctly, therefore, $\mathrm{CO}_{2}$ emission of a vehicle, to be able to estimate the amount of total $\mathrm{CO}_{2}$ emissions from heavy duty vehicles.

Two different regulatory testing methods were published by US EPA and European Council to determine the drag area $\left(C_{D} A\right)$ for $\mathrm{CO}_{2}$ certification of heavy duty vehicles. While US regulations requires "coast-down (CD)" test, EU regulations requires "constant speed (CST)" test. The objective of this study is to compare these two different regulatory approaches with their different assumptions. In order to be able to make a comparison of these two testing methods, CD and CST performed with same tractor and trailer combination, which is a Class 8 truck for US market, in same conditions.

Results yielded up to 9 percent difference between two methods. Possible cause of this difference can be listed as, the different assumptions of each testing method such as speed dependency of losses, different approaches for tire rolling resistance and some neglected or unaccounted loses. These possible reasons were also investigated individually in this study. 


\section{NOMENCLATURE}

PM: Particulate Matter

NOx: Nitrous Oxides

CO2: Carbon Di-Oxide

CO: Carbon Mono-Oxide

OEM: Original Equipment Manufacturer

EU: European Union

VECTO: Vehicle Energy Consumption Calculation Tool

US EPA: US Environmental Protection Agency

NHTSA: National Highway Traffic Safety Administration

GHG: Greenhouse Gasses

EC: European Council

WFT: Wheel Force Transducer

$C_{R R}:$ Rolling Resistance Coefficient

RPM: Revolution per Minute 
CAN bus: Controller Area Network

GPS: Global Positioning System

WVU: West Virginia University

CAFEE: Center of Alternative Fuels and Engine Emissions 


\section{Table of Contents}

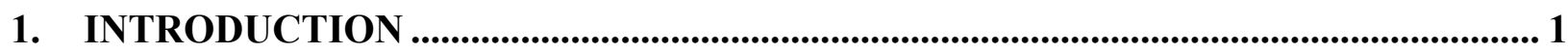

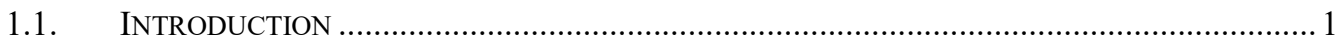

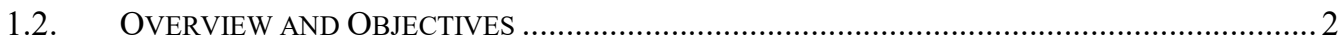

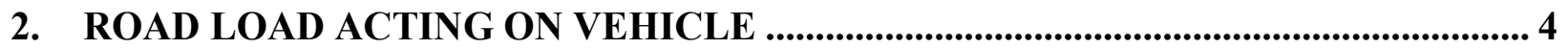

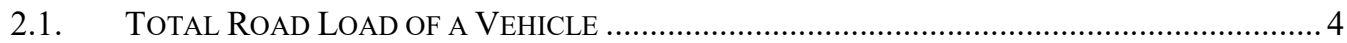

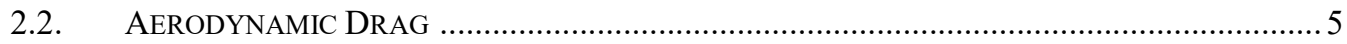

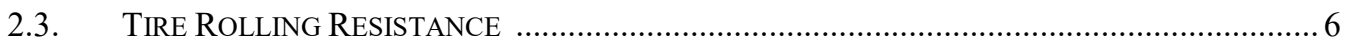

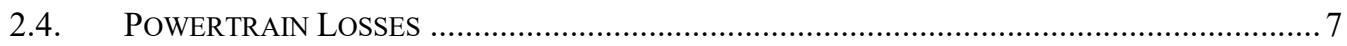

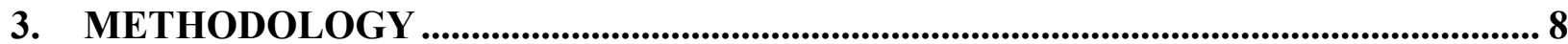

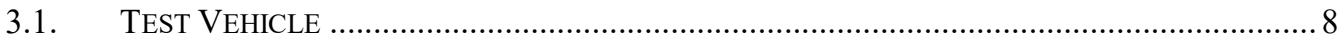

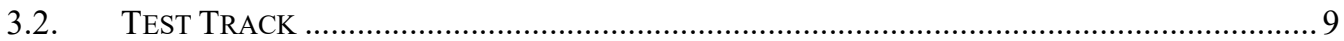

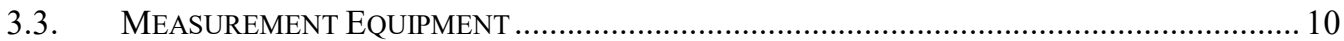

3.3.1. High-Resolution Truck Torque Wheel System ……......................................................................11

3.3.2. WVU HD Dynamometer ....................................................................................................... 13

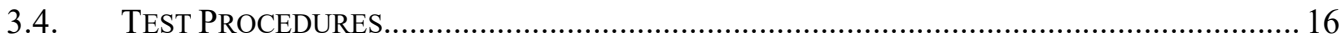

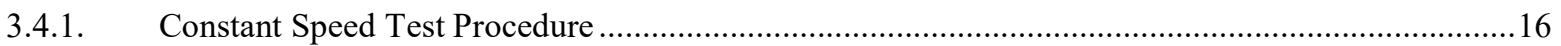

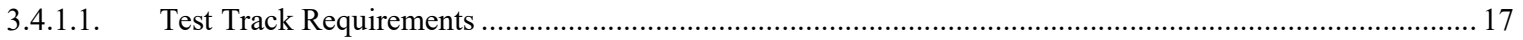

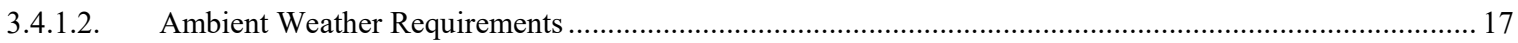

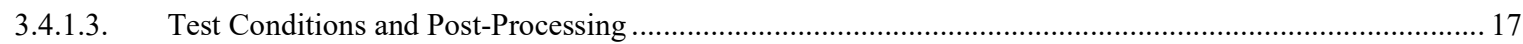

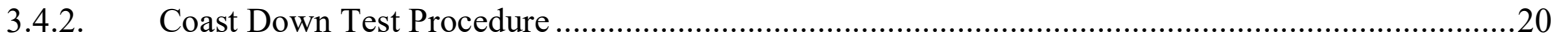

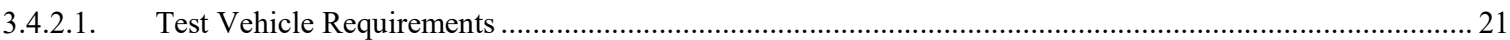

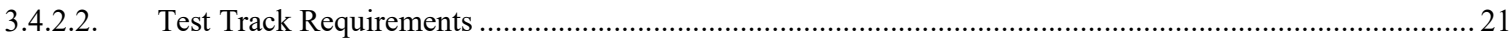




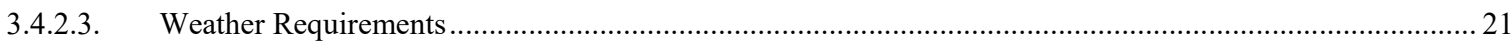

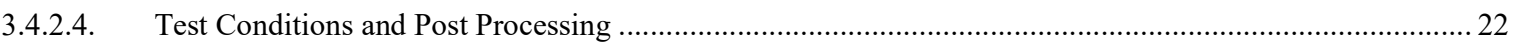

4. RESULTS AND DISCUSSION ................................................................................... 31

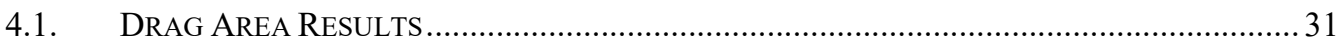

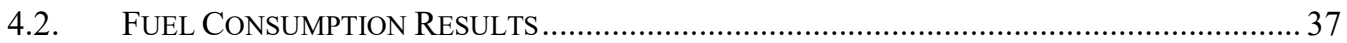

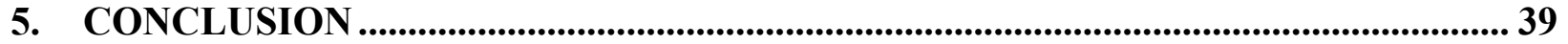

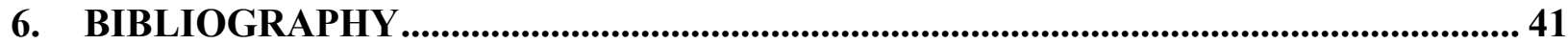




\section{List of Figures}

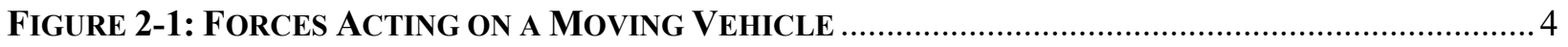

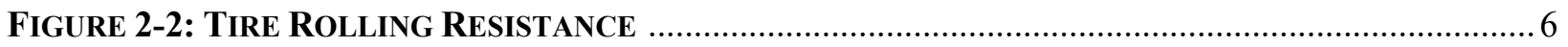

FIGURE 2-3: POWERTRAIN COAST-DOWN RESULTS OF HOT AND COLD POWERTRAIN ......................... 7

Figure 3-1: SATEllite ANd Straightaway PiCtures of MLPG ............................................ 10

FigURE 3-2: RIM, WHEEL HUB AND TRANSDUCER ASSEMBLY OF TWHR 2000............................ 11

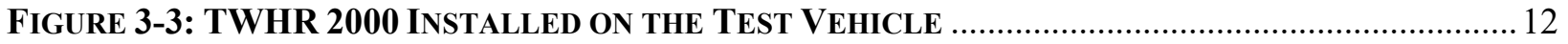

Figure 3-4: WVU HeAVy-DUty Chassis Dynamometer WheEl Hub AdAPTERS ANd Rollers 14

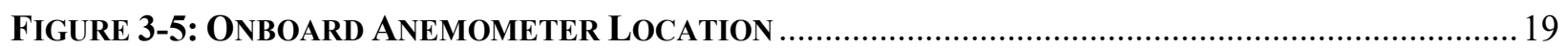

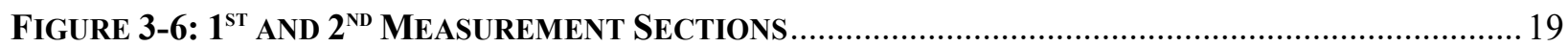

FIGURE 3-7: GRAPH OF DEFAULT AXLE SPIN LOSS AS A FUNCTION OF SPEED ..................................2 27

Figure 4-1: AVerage Fuel Consumption Breakdown of a Heavy Duty Truck for Three

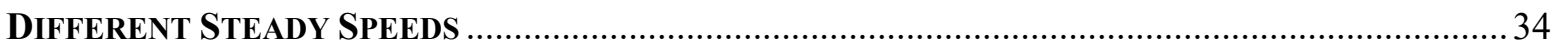

Figure 4-2: Time vS. SPEed ANd Grade Profile of VECTO Long HaUl CyCLE......................... 37 


\section{List of Tables}

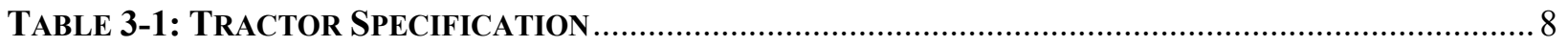

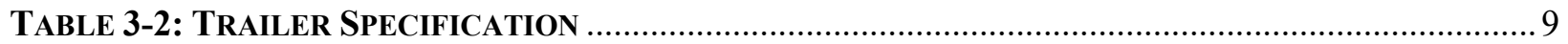

TABLE 3-3:SPECIFICATIONS OF HIGH-RESOLUTION WHEEL TORQUE METER TWHR2000 ............... 12

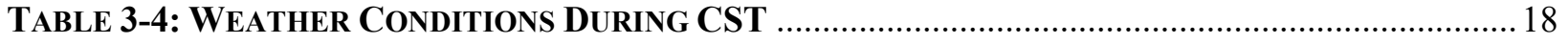

TABle 3-5: Vehicle SPEed RANGeS APPLIEd DuRING COAST DOWn TESTING .............................22

TABLE 3-6: WeATHER CONDiTIONS DuRING CoAST DoWn TESTING ..........................................2

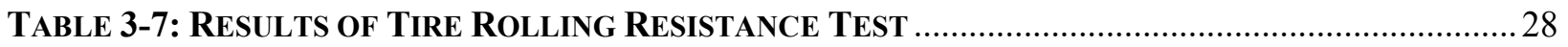

TABle 4-1Results Of VECTO - AIR DRAg FOR CONSTANT SPEED TESTING METHOD ................... 31

TABLE 4-2: ReSUlts OF INDIVIDUAL COAST DOWn TESTS WITHOUT CORRECTION .......................... 32

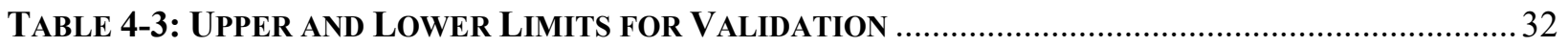

TABle 4-4: Drag AREa Comparison of Constant SPEed ANd CoAst Down Methods .............. 33

TABLE 4-5: BREAKDOWN OF ROAD LOAD CONTRIBUTIONS AFTER ELIMINATIONS DONE................. 35

TABLE 4-6: DRAG AREA RESULTS WITHOUT TRR SPEED DEPENDENCY ….......................................... 36

TABle 4-7: Fuel Consumption Results of VeCto long Haul CyCle for Different Dyno

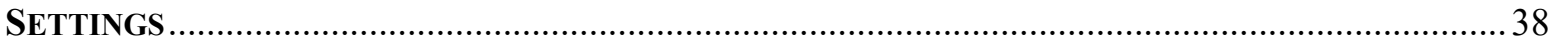




\section{Introduction}

\subsection{Introduction}

Today, the great majority of ground transportation rely on internal combustion engines. Even there have been some experimental and conceptual trials on alternative fuels and zero emission vehicles, especially, heavy duty transportation is still highly depending on diesel technology because diesel has proven itself as a reliable and economical way of transportation. However, the most concerned downside of internal combustion engines is the exhaust emissions which are highly toxic for human beings and has some bad effects on environment such as global warming and toxic fumes. Moreover, petrol as a fuel is not renewable and therefore not sustainable.

Authorities both in the United States and Europe started implementing some emissions regulations from the early 90 s and gradually tightened them to control and reduce the amount of emissions. Since then, there has been a significant progress on particulate matter $(P M)$ and oxides of nitrogen $\left(\mathrm{NO}_{x}\right)$ emissions using some after-treatment technologies like diesel particulate filters (DPF) and selective catalytic converters (SCR). However, since diesel and gasoline are hydrocarbon fuels, there are some other carbonaceous emissions such as carbon-dioxide $\left(\mathrm{CO}_{2}\right)$ and carbon-monoxide $(\mathrm{CO})$ as the natural products of the combustion process. $\mathrm{CO}_{2}$ is one of the main products of the combustion reaction of hydrocarbons with $\mathrm{H}_{2} \mathrm{O}$ and it is a well-known fact that $\mathrm{CO}_{2}$ is the largest contributor among greenhouse gases and therefore the global warming and climate change. Since $\mathrm{CO}_{2}$ is one of the main products of combustion reaction, there is no way of 
eliminating it completely with engine control and there are no commercialized $\mathrm{CO}_{2}$ after-treatment systems. However, it is possible to reduce the amount of $\mathrm{CO}_{2}$ emission with less fuel consumption.

\subsection{Overview and Objectives}

Currently $25 \%$ of the road transport $\mathrm{CO}_{2}$ emissions are from heavy-duty vehicles like lorries, trucks, busses and coaches and authorities expect a further increase in the future if no additional measures taken. European Union is planning to reduce the $\mathrm{CO}_{2}$ emissions $60 \%$ by the year 2050 [1]. Until now, there have been no method or regulations implemented to measure $\mathrm{CO}_{2}$ emissions or fuel consumption for heavy-duty vehicles. Therefore, it is not possible to objectively compare the $\mathrm{CO}_{2}$ emissions and fuel consumption performance of vehicles. In order to be able to compare and declare the $\mathrm{CO}_{2}$ emissions and fuel consumption and encourage the OEMs to build more efficient vehicles, EC decided to develop a simulation software which is publicly available, open-source, downloadable and executable, so they developed Vehicle Energy Consumption Calculation Tool (VECTO) and introduced it for European vehicle type approval regulation on May 2017.

Similarly, US Environmental Protection Agency (EPA) and National Highway Traffic Safety Administration (NHTSA) states that $26 \%$ of the greenhouse gas (GHG) emissions in the United States come from transportation[2]. In order to reduce GHG emissions, they published the first phase of GHG emissions standards in 2011 and the standards became mandatory with the vehicles model year 2014. The second phase was published in 2016 and it will be phased in at 2027. EPA expects $17 \%$ lower $\mathrm{CO}_{2}$ emissions at 2020 and $26-28 \%$ lower at 2025 than 2005 and 
the target is $80 \%$ lower $\mathrm{CO}_{2}$ emissions by the 2050 [2]. Again, similarly with the EU, the Greenhouse Gas Emissions Model (GEM), which is a publicly available and executable simulation tool, was released in 2011.

Both EC and US EPA introduced regulations for $\mathrm{CO}_{2}$ certification, and they defined different approaches and test procedures to determine the road load acting on the vehicle tested. Since, fuel consumption therefore $\mathrm{CO}_{2}$ emission is directly related with the road load, two different approaches may yield to different results.

While European side measures the total torque on the wheels by wheel force transducers (WFT), US side uses coast-down method to determine the total road load of the vehicle.

The main objective of this thesis is to compare the results of two different approaches which are the European approach and US approach. Test procedures are clearly defined on the regulatory papers of Commission Regulation (EU) 2017/2400, 2017 [1] for the European side and Federal Register/Vol. 81, No. 206, 2016 [2] for the US side. 


\section{ROAD LOAD ACTING ON VEHICLE}

\subsection{Total Road Load of a Vehicle}

Long haul trucks generally travel interstate and use highways at constant speed. It means that there is no acceleration or deceleration. As Sir Isaac Newton described by the second law of motion $^{1}$, it can be easily said that total force acting on a vehicle must be zero if there is no acceleration or deceleration. Hence, it means that the engine is doing work only to overcome the road load acting on the vehicle which consists of aerodynamic drag, rolling resistance of tires, mechanical losses caused by powertrain of the vehicle and gravitational force if there is slope on the road. Those forces will be explained in detail in the further sections.

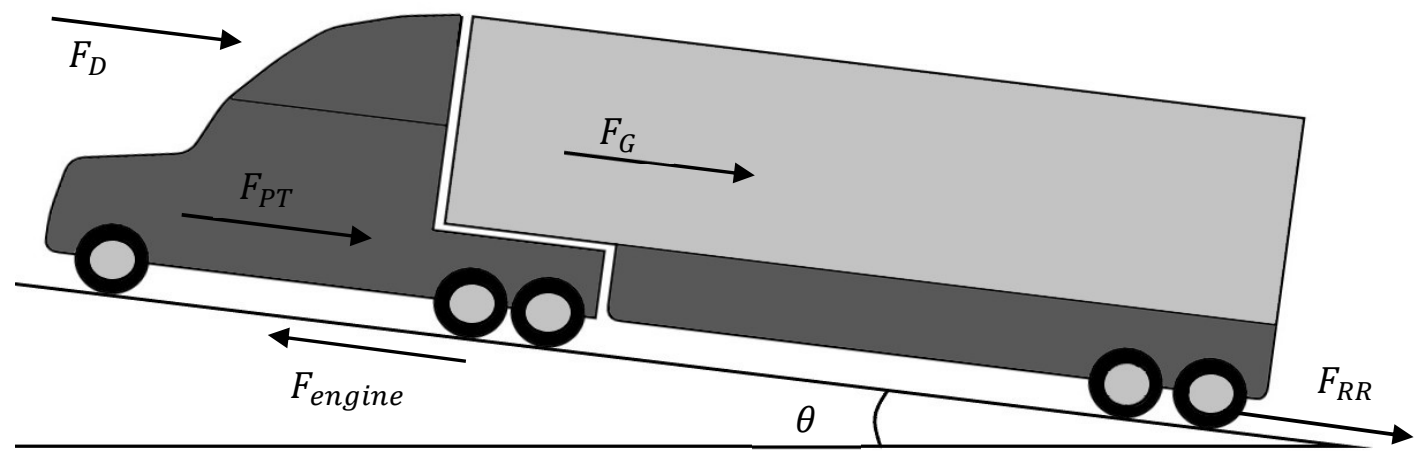

Figure 2-1: Forces Acting on a Moving Vehicle

So;

$$
F_{\text {net }}=F_{\text {engine }}-F_{D}-F_{G}-F_{P T}-F_{R R}=m_{e} \frac{d V}{d t}
$$

$$
{ }^{1} F_{n e t}=m_{e} \frac{d V}{d t}
$$




\subsection{Aerodynamic Drag $\left(F_{D}\right)$}

Aerodynamic drag is the force which is acting opposite to the direction of relative motion due to the motion of the object through the fluid. Mainly, there are 3 factors which affect aerodynamic drag and they can be listed as; Geometry of the object, the motion of the surrounding fluid (velocity of the vehicle, therefore, the velocity of fluid) and properties of the fluid [3]. In our case, because the vehicle is surrounded by air, air properties will be used. Aerodynamic drag can be found by the following equation.

$$
F_{D}=\frac{1}{2} \rho v^{2} C_{D} A
$$

Where;

$F_{D}$ is the drag force,

$\rho$ is the density of the fluid,

$v$ is the speed of the vehicle relative to the fluid,

$C_{D}$ is the drag coefficient, a dimensionless number,

$A$ is the cross-sectional area of the vehicle.

As it can be seen at equation 2.2, aerodynamic drag is a function of the density of air, speed of air, drag coefficient and cross-sectional area of the vehicle. Drag coefficient is a dimensionless quantity which is used to model all the complex dependencies of shape and flow conditions and generally it is found experimentally[3]. 


\subsection{Tire Rolling Resistance $\left(F_{R R}\right)$}

Tire rolling resistance can be defined as the energy dissipated by a tire per unit of distance covered due to the visco-elastic effect of the material of tires made (i.e. rubber) [4]. Tire rolling resistance is a function of the load on the tire and the speed of the tire and can be written as;

$$
F_{R R}=n_{t} P^{\propto}\left(\frac{L}{n_{t}}\right)^{\beta}\left(a+b \bar{v}+c \bar{v}^{2}\right)
$$

Where;

$\propto, \beta, a, b$ and $c$ are the tire rolling resistance regression coefficient,

$n_{t}$ is the number of tires,

$P$ is the cold inflation pressure $[\mathrm{kPa}]$,

$L$ is the load over the axle [N],

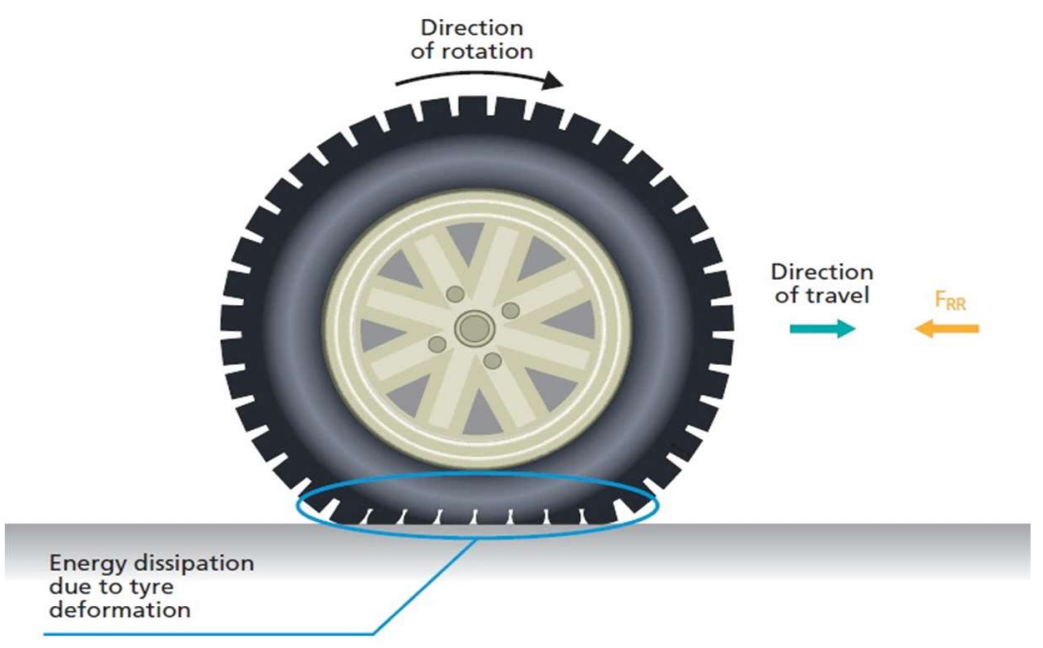

Figure 2-2: Tire Rolling Resistance (Retrieved from: The Tyre Rolling Resistance and Fuel Savings, Michelin, 2003) 


\subsection{Powertrain Losses $\left(F_{P T}\right)$}

Powertrain of a vehicle comprises the main components which generate power and deliver it to the wheels. Powertrain of a heavy-duty vehicle mainly consists of the engine, transmission, drive shaft, differential gears and axles. Although most of these components have high efficiencies, there is still a considerable amount of power loss due to the friction of gears, bearings and brake pads and oil splash in the transmission and differential gear box. In order to determine the overall power loss of a powertrain, all of those components need to be tested individually. Stenvall (2010) found in his research that powertrain losses of a heavy-duty truck are highly and exponentially dependent on the speed of the vehicle and the temperature of the lubrication fluids used in the components of the powertrain. At Figure 2-3, his experimental results of the powertrain coastdown are shown [5].

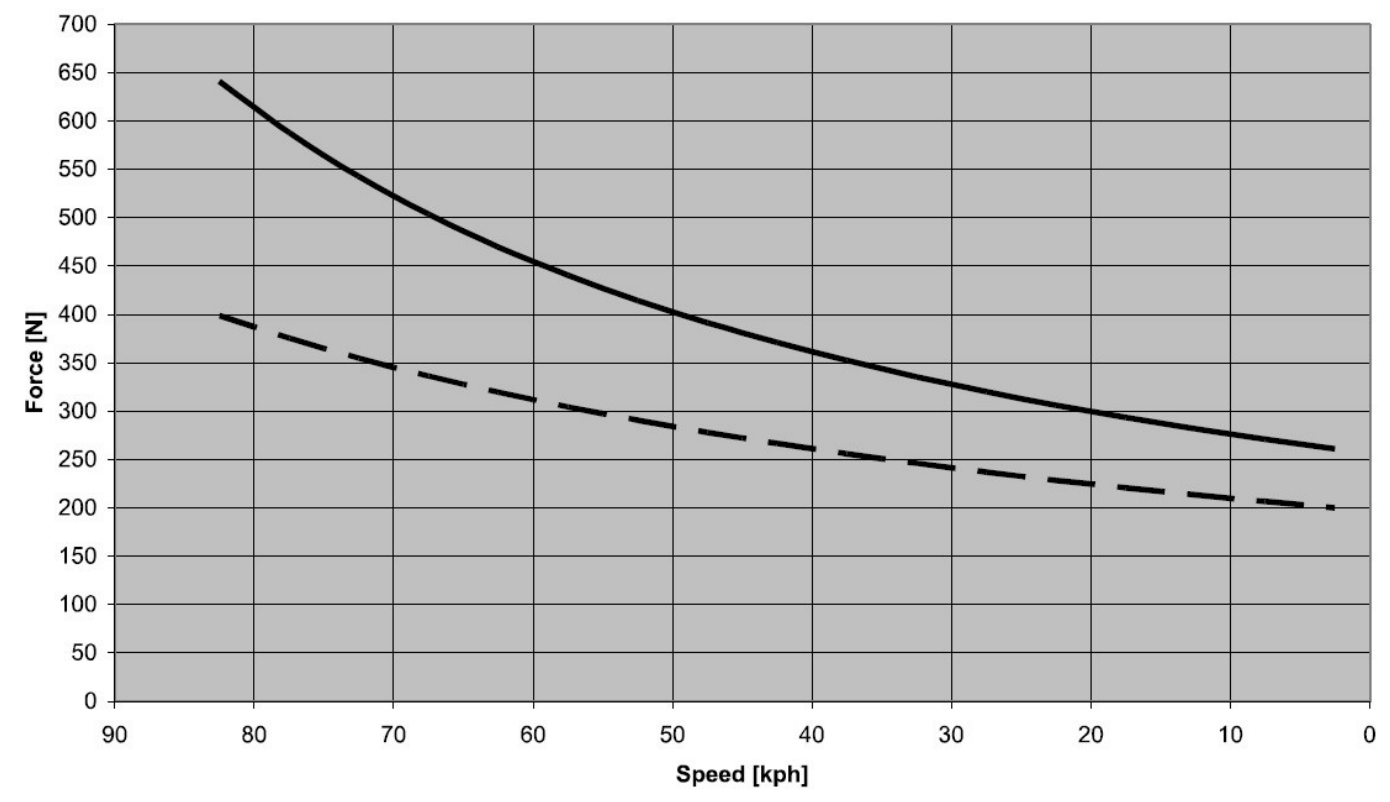

Cold transmission - Warm transmission

Figure 2-3: Powertrain coast-down results of hot and cold powertrain (adapted from: Stenvall (2010)) 


\section{METHODOLOGY}

\subsection{Test Vehicle}

For all the tests, a sleeper cab, high roof US Class 8 semi-trailer truck combination used. The tractor and trailer were selected to represent the best available technology in 2015 and was OEM stock without any after-market modifications. Weight of the vehicle during the tests was $17209 \mathrm{~kg}$. Table 3.1, provides the specifications of the tractor used in this study.

Table 3-1: Tractor Specification

\begin{tabular}{|l|c|}
\hline Vehicle Class & Class 8 \\
\hline Cabin Type & Sleeper Cab, High Roof \\
\hline Engine Volume [liter] & 14 to 15 \\
\hline Number of Cylinders & Inline 6 \\
\hline Engine Torque [Nm] & 2170 to 2440 \\
\hline Engine Power [kW] & 298 to 315 \\
\hline Emission Standard & US-EPA 2010 \\
\hline Emission Control & EGR, DOC, DPF, SCR \\
\hline Transmission Type & AMT \\
\hline Number of Gears & 12 \\
\hline Axle Configuration & $6 x 4$ \\
\hline Axle Type & Tandem Rear Axle \\
\hline 1st and 12th Gear Ratios & 14.928 and 1.00 \\
\hline Axle Ratio & 2.43 \\
\hline GVW [metric ton] & 20.4 \\
\hline Vehicle curb mass [ton] & 9.26 \\
\hline Tires & US EPA Verified SmartWay Low RR (275/80R 22.5) \\
\hline
\end{tabular}


The trailer used for this study was a 2-axle, spring-ride composite plate van. It had U.S. EPA verified SmartWay Technology certified side skirts and low rolling resistance tires for reduced drag. Table 3.2 provides the specifications of the trailer used for this study.

Table 3-2: Trailer Specification

\begin{tabular}{|l|c|}
\hline Side Skirts & Fuel efficient, aerodynamic advanced trailer skirt - \\
\hline Tires & U.S. EPA Verified SmartWay Technology \\
& 295/75R 22.5 low rolling resistance radial tires - \\
\hline Length [m] & U.S. EPA Verified SmartWay Technology \\
\hline Width [m] & 2.6 \\
\hline Height [m] & 4.1 \\
\hline Empty weight [metric ton] & 7.95 \\
\hline
\end{tabular}

\subsection{Test Track}

All of the tests were completed at Michelin's Laurens Proving Ground (MLPG) facility in Laurens SC, USA. MLPG has 9 different tracks. All of the tests were performed at Track 9 which is most suitable for coast-down tests. Track 9 had $1463 \mathrm{~m}$ straightaway section with almost no grade. Track width was varying between $12 \mathrm{~m}$ and $20 \mathrm{~m}$. The surface material of Track 9 was asphalt with the texture of smooth at the macro scale and rough at the microscale. There were no obstacles or any bridges and construction near the measurement section which may disturb the 
wind flow or wake of the vehicle. At the ends of Track 9, there were oval sections which make possible to gain speed until measurement sections.

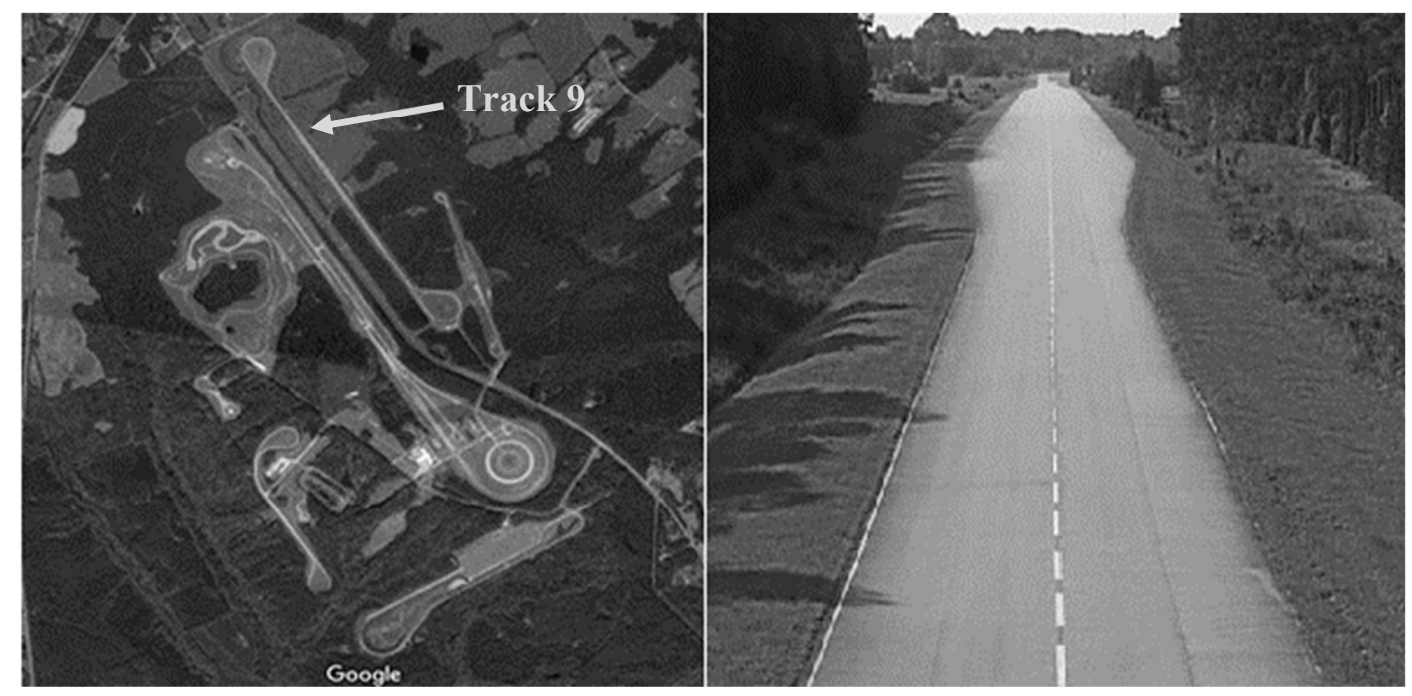

Figure 3-1: Satellite and Straightaway Pictures of MLPG

\subsection{Measurement Equipment}

For wheel-torque measurements Michigan Scientific Corporation TWHR2000 system used for all the tests. Vehicle speed and position collected with GPS and for comparison, vehicle speed from CAN bus also recorded. Moreover, engine speed signal of CAN bus logged. In order to determine the yaw angle, a Gill Instruments Windsonic 75 model ultrasound anemometer placed 1.5 meters above to the vehicle with a K-type thermocouple to measure the ambient temperature. Detailed specifications of the measurement systems will be provided following sections.

Data acquisition was done by an in-house software developed by West Virginia University, Center for Alternative Fuels and Engine Emissions (WVU CAFEE). 


\subsubsection{High-Resolution Truck Torque Wheel System}

In order to measure the wheel torque "The Michigan Scientific TWHR2000-High Resolution Truck Wheel System" was used. This system was specifically designed to measure small variations in wheel torque on highway conditions. It can measure toques in the range of $\pm 2700 \mathrm{Nm}$ within the $2.7 \mathrm{Nm}$ accuracy over the entire measurement range. Moreover, it can measure the wheel speeds up to 1800 RPM. The torque transducer mounts between the tire and vehicle hub with hub adapters and modified wheel rims. Therefore, torque must pass through the transducer before being transferred to the surface. Table 3-3 below gives the specifications of the TWHR 2000 and Figure 3-2 and Figure 3-3 shows the modified rim, hub adapter and, transducer assembly and the application on the test vehicle respectively [6].

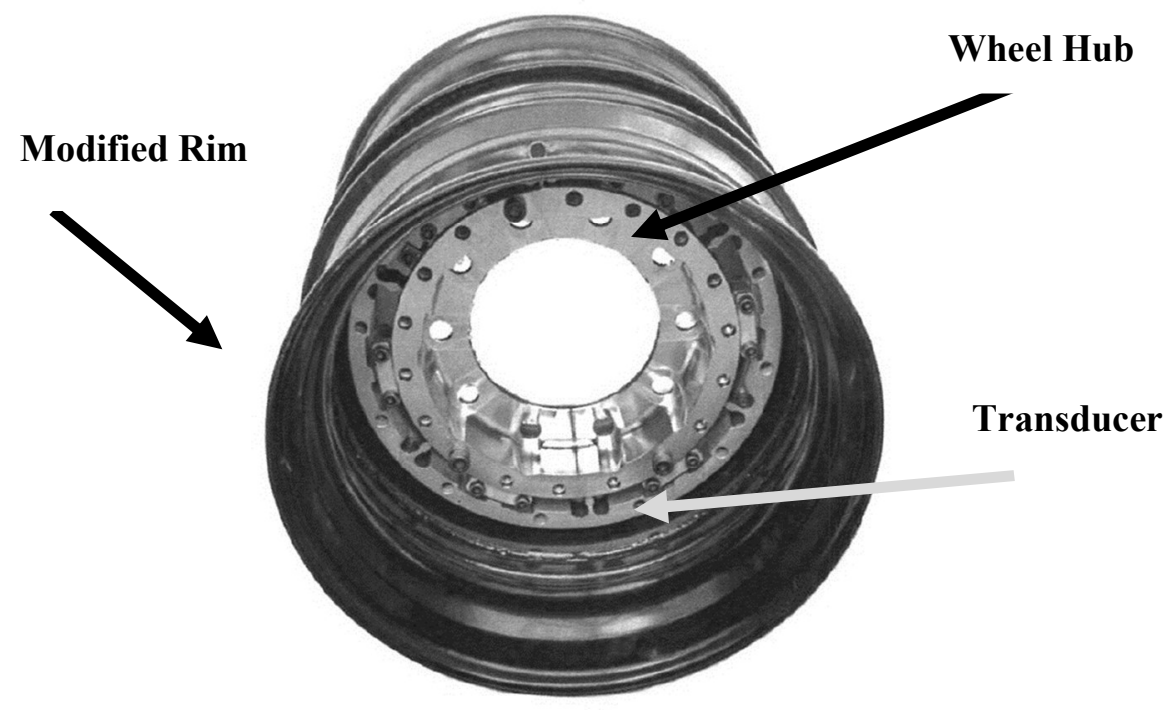

Figure 3-2: Rim, Wheel Hub and Transducer Assembly of TWHR 2000 
Table 3-3:Specifications of High-Resolution Wheel Torque Meter TWHR2000

\begin{tabular}{|l|c|}
\hline Manufacturer & Michigan Scientific Corporation \\
\hline Model & TWHR2000 \\
\hline Maximum Load Capacity & $\pm 27,000 \mathrm{Nm}$ \\
\hline Full-Scale Measurable Load & $\pm 2,700 \mathrm{Nm}$ \\
\hline Accuracy & $3 \mathrm{Nm}$ \\
\hline Sensor & $0.12 \%$ of full-scale output \\
\hline Nonlinearity & $0.05 \%$ of full-scale output \\
\hline Hysteresis & $-40{ }^{\circ} \mathrm{C}$ to $93^{\circ} \mathrm{C}$ \\
\hline Temperature Range, Compensated & $-40{ }^{\circ} \mathrm{C}$ to $149{ }^{\circ} \mathrm{C}$ \\
\hline Temperature Range, Practical & $10 \mathrm{VDC}$ \\
\hline Excitation Voltage, Maximum & \\
\hline
\end{tabular}

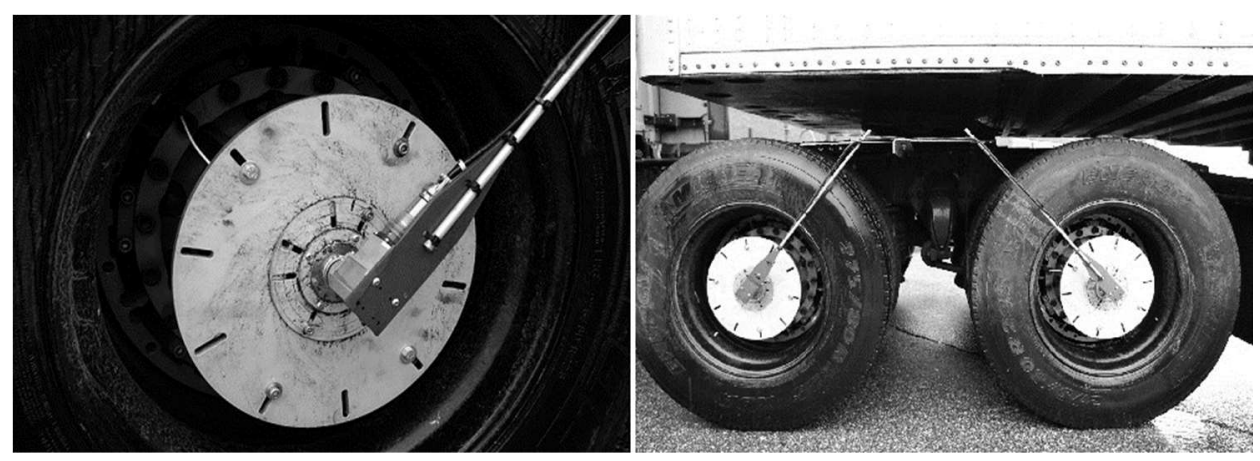

Figure 3-3: TWHR 2000 Installed on the Test Vehicle 


\subsubsection{WVU HD Dynamometer}

Fuel consumption testing for this study performed on WVU's heavy duty-chassis dynamometer. WVU heavy-duty dynamometer was designed and built by WVU workers and researchers. It was designed as a transportable dynamometer and it can be integrated into a semitrailer frame with tandem-axle and can be transported to different test fields.

It applies brake to the wheels by eddy current power absorbers with specially designed wheel hub adapters in order to simulate the desired road load. The advantage of using hub adapters instead of rollers is the elimination of the slippage between tire and rollers. Moreover, it is safer in terms of possible tire overheating and therefore damage because of the heat production due to slippage. Brake force is only applied from one driven axle and the other axle rests on the freespinning rollers. WVU's heavy-duty dynamometer is able to simulate different gross vehicle masses varying approximately from $24,000 \mathrm{lbs}$ to $66,000 \mathrm{lbs}$ with using different configurations of inertial flywheels. It consists of several components such as tire rollers, hub adapters, differential gearboxes, flywheel assemblies, torque and speed transducers and eddy current power absorber units. Moreover, in order to simulate down grades, there are two $20 \mathrm{hp} \mathrm{AC}$ electric motors. 


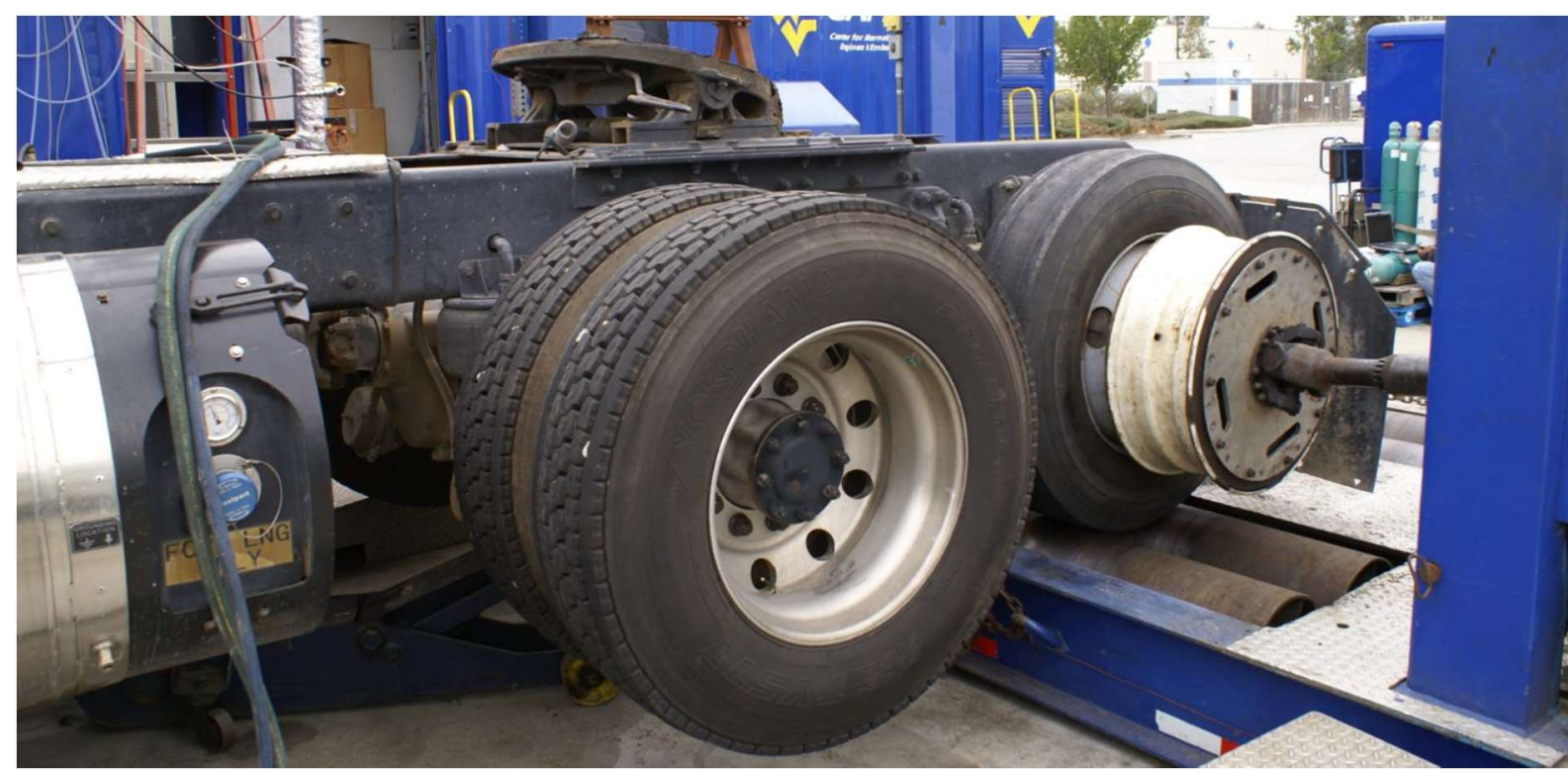

Figure 3-4: WVU Heavy-Duty Chassis Dynamometer Wheel Hub Adapters and Rollers (Adapted from: Demirgok, (2018))

- Tire Rollers: WVU's heavy-duty dyno consists of two sets of free-spinning rollers. Their purpose is to support the vehicle axles. The rollers configuration provides flexibility to test single or tandem axle vehicles as well as single or dual driven axles. Moreover, they can transfer some amount of unbalanced torque and provide uniform rotational speed to the wheels with the help of flexible couplings.

- Hub Adapters: The purpose of the hub adapters is transferring the braking torque supplied by the eddy current power absorbers to the drive axle.

- Eddy Current Power Absorbers: There are two $300 \mathrm{hp}$, air cooled eddy current power absorbers (Mustang CC300) on the dynamometer configuration. They are 
capable of absorbing $300 \mathrm{hp}$ continuously and $1000 \mathrm{hp}$ intermittently during peak operation. They are controlled by PID controller system to provide a quick and smooth operation.

- Flywheel Assembly: The flywheel assembly can simulate different vehicle masses by different flywheel masses and arrangements. During acceleration, they apply inertial resistance to the wheels to simulate the vehicle's and trailer's mass. While the vehicle braking they provide inertial force to the eddy current power absorbers.

- Variable Speed AC Motor: a $20 \mathrm{hp}$ variable speed motor is attached to the powertrain of the dynamometer to simulate the down grade motoring effect of the vehicle's mass.

The road load applied to the vehicle is determined by the road load power equation which is function of vehicle speed $(V)$, drag area of the vehicle $\left(C_{D} A\right)$, ambient air density $(\rho)$, mass of the vehicle $(m)$ and rolling resistance coefficient $(\mu)$. Road load equation can be seen as equation 3-1.

$$
P_{r}=\mu m g V+\frac{1}{2} \rho C_{D} A V^{3}
$$

Road load applied to the vehicle is determined by the speed of the vehicle at that moment since rolling resistance coefficient, vehicle mass, air density and drag area in this function are constant. 


\subsection{Test Procedures}

\subsubsection{Constant Speed Test Procedure}

European constant speed test procedure is defined at ANNEX VIII under Commission Regulation (EU) 2017/2400. Driving torque, vehicle speed, air flow velocity on the vehicle and yaw angle shall be measured for two different constant vehicle speeds in a sequence first low speed then high speed and low speed again.

- Low Speed: Average speed within the measurement section must be in between 10 to $15 \mathrm{~km} / \mathrm{h}$ and stability criteria is defined as:

$$
\bar{v}_{l m s}-0.5 \mathrm{~km} / \mathrm{h} \leq \bar{v}_{l m} \leq \bar{v}_{l m s}+0.5 \mathrm{~km} / \mathrm{h}
$$

Where:

$\bar{v}_{l m s}=$ average vehicle speed per measurement section $[\mathrm{km} / \mathrm{h}]$.

$\bar{v}_{l m}=$ central moving average of vehicle speed with time needed to drive $25 \mathrm{~m}$ distance at actual vehicle speed seconds time base $[\mathrm{km} / \mathrm{h}]$.

- High Speed: Average maximum speed within the measurement section must be in between $95 \mathrm{~km} / \mathrm{h}$ and average minimum speed must be $85 \mathrm{~km} / \mathrm{h}$ or $3 \mathrm{~km} / \mathrm{h}$ less than the maximum vehicle speed available at the test track. Stability criteria for high-speed test is defined as:

$$
\bar{v}_{h m s}-0.3 \mathrm{~km} / \mathrm{h} \leq \bar{v}_{h m} \leq \bar{v}_{h m s}+0.3 \mathrm{~km} / \mathrm{h}
$$


Low, high and low speed tests shall be performed in sequence. Low speed test duration shall not exceed 20 minutes in order to prevent cooling down of the warm components of the vehicle. For High speed test at least 10 passing per heading shall be performed.

\subsubsection{Test Track Requirements}

- Both tests shall be repeated for each driving directions for $250 \mathrm{~m}$ straight measurement section with a $\pm 3 \mathrm{~m}$ tolerance.

- The longitudinal slope shall not exceed \pm 1 percent and slope variations should not affect the speed and torque stabilization. The surface of the measurement sections shall have concrete or asphalt and surface temperature shall not exceed $40^{\circ} \mathrm{C}$.

\subsubsection{Ambient Weather Requirements}

- The ambient temperature shall not be less than $0^{\circ} \mathrm{C}$ and more than $25^{\circ} \mathrm{C}$.

- The road surface must be dry.

- Average wind speed must be less than or equal to $5 \mathrm{~m} / \mathrm{s}$.

- Gust wind speed must be less than or equal to $8 \mathrm{~m} / \mathrm{s}$.

- Average yaw angle must be less than or equal to 3 degrees.

\subsubsection{Test Conditions and Post-Processing}

Constant speed tests were performed at January $1^{\text {st }} 2018$. The test had 2 driven axles $(6 \times 4$ configuration). Each axle equipped with Michigan Scientific TWHR 2000 High Resolution Truck Torque Wheel System. For air flow velocity and yaw angle measurements, a Gill Instrument Windsonic 75 anemometer was placed to the leading edge of the trailer at a height of $1.5 \mathrm{~m}$ above 
the top of the trailer. Figure 3-4 below shows the anemometer placement on the test vehicle. Additionally, a K-type thermocouple was placed to the pole of the anemometer in order to measure ambient temperature. Weather data is obtained from MLPG's stationary weather station which was located at the south turning section of the Track 9. All weather conditions during the constant speed tests were compliant with the European regulatory requirements. Table 3-4 shows the weather conditions during the CST

Table 3-4: Weather Conditions During CST

\begin{tabular}{|l|c|}
\hline Track Surface condition & Dry \\
\hline Average Ambient Temperature & $19.7^{\circ} \mathrm{C}$ \\
\hline Average Wind Speed & $1.5 \mathrm{~m} / \mathrm{s}$ \\
\hline Average Barometric Pressure & $1031.0 \mathrm{mbar}$ \\
\hline Average relative Humidity & $38.1 \%$ \\
\hline Average Track Surface Temperature & $25^{\circ} \mathrm{C}$ \\
\hline
\end{tabular}

Post processing done by Vehicle Energy Consumption Calculation Tool - Air Drag (VECTO - Air Drag) which was released by European Council. It is a regulatory software and it performs data validation, filtering and calibration. If the input test data passes the validity criteria, it calculates the drag area and rolling resistance coefficient of the tires. First of all, mobile anemometer misalignment test must be done. Track 9 has a length of $1463 \mathrm{~m}$, so it was enough to have two $250 \mathrm{~m}$ measurements on one pass. Figure $3-5$ shows the $1^{\text {st }}$ and $2^{\text {nd }}$ measurement sections. 


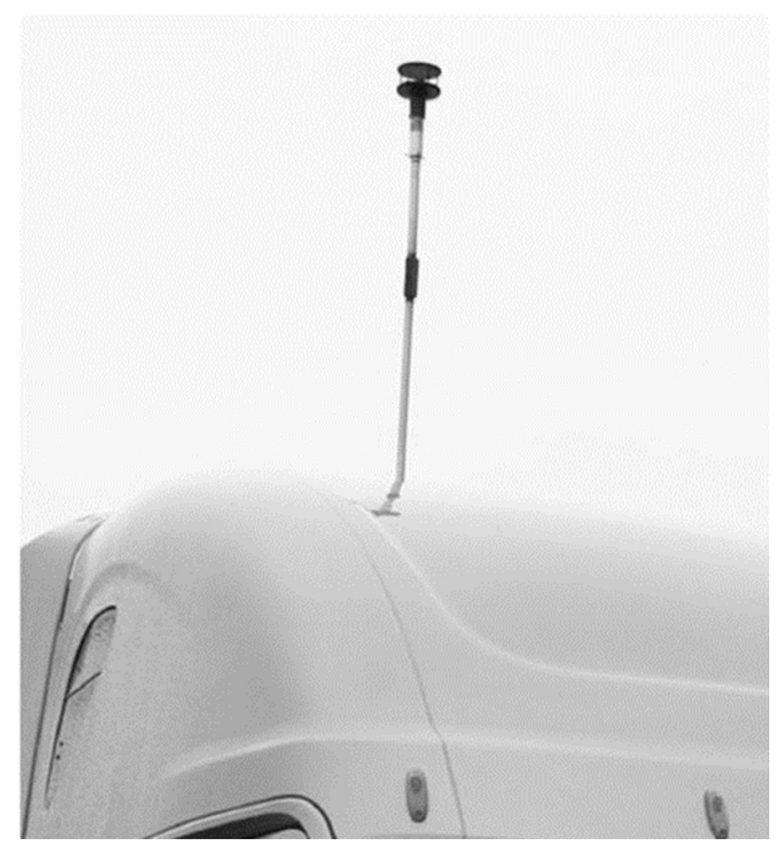

Figure 3-5: Onboard Anemometer Location

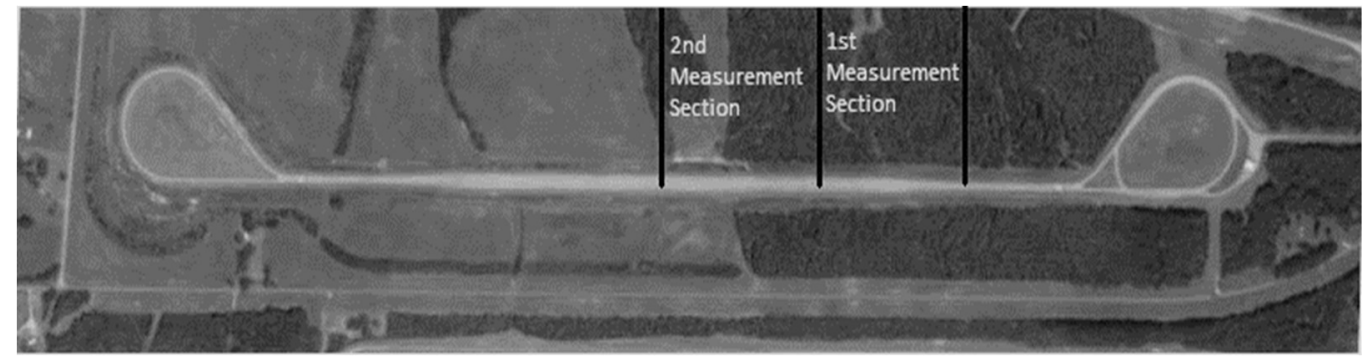

Figure 3-6: $1^{\text {st }}$ and $2^{\text {nd }}$ Measurement Sections

Start and end points coordinates of the measurement sections with headings, section and direction IDs shall be defined and input to the VECTO in appropriate format. Moreover, test data with all the signals shall be provided to the software in appropriate format. 
After misalignment calculations done, ambient data, actual test sections and data for one high speed and two low speed tests data shall be provided to the software to find the drag area. 12 passes for each direction performed which results 24 measurements for each direction for each speeds. Results of the VECTO will be presented in the Chapter 4.

\subsubsection{Coast Down Test Procedure}

U.S. EPA clearly describes the coast down test procedure for GHG certification of Phase 2 tractors under the CFR Title 40, Part 1037.528, 2017[7]. Coast down method is relatively easier than constant speed since it only needs vehicle speed and air flow. Two methods are described for coast down test.

- Complete Coast Down Runs: In this method, vehicle shall be operated at a top speed above $115 \mathrm{~km} / \mathrm{h}$ and then allow it to coast down to $13 \mathrm{~km} / \mathrm{h}$ at neutral gear. After, data for high speed range $(115 \mathrm{~km} / \mathrm{h}$ to $93 \mathrm{~km} / \mathrm{h})$ and low speed $(35 \mathrm{~km} / \mathrm{h}$ to $13 \mathrm{~km} / \mathrm{h})$ should be taken out from the complete coast down. If test track length is not enough to perform a complete coast down test, it is possible to perform split coast down runs.

- Split Coast Down Runs: In this method, coast down runs for high and low speed segments shall be done separately. First, a test segment on the test track should be defined. Then, high speed (115 km/h to $93 \mathrm{~km} / \mathrm{h}$ ) and low speed (35 km/h to $13 \mathrm{~km} / \mathrm{h})$ coast downs shall be performed over the define test segment. Same number of measurements shall be done for the opposite direction. 


\subsubsection{Test Vehicle Requirements}

- Tires must be SmartWay verified or have a rolling resistance coefficient at or below $5.1 \mathrm{~kg} / \mathrm{metric}$ ton.

- Tires must have at least $3250 \mathrm{~km}$ mileage but have no less than 50 percent of their original tread depth.

- Tires must not be retreaded or have any signs of chunking or uneven wear.

\subsubsection{Test Track Requirements}

- Road grade shall be less than 0.02 percent over the test surface. Otherwise, grade should be taken into consideration as a function of distance. Road grade may exceed 0.5 percent for limited portions as long as it does not affect the coast down results.

- Road surface temperature must be at or below $50^{\circ} \mathrm{C}$.

\subsubsection{Weather Requirements}

- The average component of the wind speed parallel to the test direction must not exceed 6 $\mathrm{m} / \mathrm{s}$.

- An onboard anemometer shall be mounted at least $1.5 \mathrm{~m}$ above the top of the leading edge of the trailer in order to measure the yaw angle and wind speed.

- Another anemometer shall be placed the closest possible point to the midway of the test track. It must be at least $16 \mathrm{~m}$ away from the closest obstacles like trees or walls and $8 \mathrm{~m}$ away from the nearest bush. 


\subsubsection{Test Conditions and Post Processing}

For the coast down methodology, test procedure described at CFR Title 40, Part 1037.528, 2017 was followed. Tests were performed at same track (Track 9) and same day with CST. Since, the length of the Track 9 was not enough to perform full coast down, split coast down method used. Table 3-5 shows speed ranges applied during testing.

Table 3-5: Vehicle Speed Ranges Applied During Coast Down Testing

\begin{tabular}{|c|c|c|c|c|}
\hline \multicolumn{2}{|c|}{ Coast Down Section } & $\begin{array}{c}\text { Upper Speed } \\
\text { Limit }[\mathrm{km} / \mathrm{h}]\end{array}$ & $\begin{array}{c}\text { Lower Speed } \\
\text { Limit }[\mathrm{km} / \mathrm{h}]\end{array}$ & $\begin{array}{c}\text { Nominal Speed } \\
{[\mathrm{km} / \mathrm{h}]}\end{array}$ \\
\hline \multirow{2}{*}{ High Speed Range } & Start Point & 115.9 & 109.4 & 112.6 \\
\cline { 2 - 5 } & End Point & 99.8 & 93.3 & 96.5 \\
\hline \multirow{2}{*}{ Low Speed Range } & Start Point & 35.4 & 29.0 & 32.2 \\
\cline { 2 - 5 } & End Point & 19.3 & 12.9 & 16.1 \\
\hline
\end{tabular}

In total, 6 high speed accompanying low speed passes per direction (South heading and North heading) executed. At the beginning of the tests, track surface was wet due to raining weather. During the tests, it was slightly rainy. However, at the last South heading test weather conditions got worsened and it started raining heavy and water accumulation on the test track was observed. Therefore, last south heading test excluded from calculations since, it would cause faulty measurements because of water splash and hydroplaning. Table 3-6 illustrates weather conditions during testing. 
Table 3-6: Weather Conditions During Coast Down Testing

\begin{tabular}{|l|c|}
\hline Track Surface condition & Wet \\
\hline Average Ambient Temperature & $14.3^{\circ} \mathrm{C}$ \\
\hline Average Wind Speed & $0.44 \mathrm{~m} / \mathrm{s}$ \\
\hline Average Barometric Pressure & $1027.0 \mathrm{mbar}$ \\
\hline Average relative Humidity & $50.5 \%$ \\
\hline Average Track Surface Temperature & $25^{\circ} \mathrm{C}$ \\
\hline
\end{tabular}

Post processing is clearly described step by step at CFR Title 40, Part 1037.528, 2017. First, theoretical air speed $\left(v_{\text {air }, \text { th }}\right)$ should be calculated from the data obtained from mobile anemometer placed on the test vehicle.

$$
v_{a i r, t h}=\sqrt{w^{2}+v^{2}+2 \cdot v \cdot w \cdot \cos \left(\varphi_{w}+\varphi_{v e h}\right)}
$$

Where:

$w=$ Filtered wind speed.

$v=$ Filtered vehicle speed

$\varphi_{w}=$ Filtered wind direction.

$\varphi_{v e h}=$ The vehicle direction. 
After calculating theoretical air speed, measured air speed was corrected by coefficients obtained from linear regression.

$$
\begin{aligned}
& v_{\text {air }, \mathrm{th}}=\alpha_{0}+\alpha_{1} \cdot v_{\text {air,meas }} \\
& v_{\text {air }}=\alpha_{0}+\alpha_{1} \cdot v_{\text {air,meas }}
\end{aligned}
$$

Measured air direction also must be corrected. Theoretical air direction can be calculated using the equation below.

$$
\Psi_{a i r, t h}=\arctan \left(\frac{w \cdot \sin \left(\varphi_{w}+\varphi_{v e h}\right)}{v+w \cdot \cos \left(\varphi_{w}+\varphi_{v e h}\right)}\right)
$$

Correction coefficients shall be calculated by linear regression.

$$
\begin{gathered}
\Psi_{\text {air }, \mathrm{th}}=\beta_{0}+\beta_{1} . \Psi_{\text {air,meas }} \\
\Psi_{\text {air }}=\beta_{0}+\beta_{1} \Psi_{\text {air }, \text { meas }}
\end{gathered}
$$

Effective mass $\left(M_{e}\right)$ needs to be calculated by adding the rotational inertia of the wheels. $56.7 \mathrm{~kg}$ for each tire shall be added to test weight. Since the test vehicle had 18 wheels, total effective mass found as $18229.6 \mathrm{~kg}$. Afterwards road load acting on a vehicle should be calculated for high and low speed ranges by the following equation.

$$
F=-M_{e} \cdot \frac{\bar{v}_{\text {start }}-\bar{v}_{\text {end }}}{\bar{t}_{\text {start }}-\bar{t}_{\text {end }}}+a_{g} \cdot \frac{\bar{h}_{\text {start }}-\bar{h}_{\text {end }}}{\left|\bar{D}_{\text {start }}-\bar{D}_{\text {end }}\right|}
$$


Where:

$\bar{v}=$ Average vehicle speed in $\mathrm{m} / \mathrm{s}$ at the start or end of each speed range with $\pm 3.2 \mathrm{~km} / \mathrm{h}$ binning.

$\bar{t}=$ Timestamp at which the vehicle reaches the starting or ending speed in seconds.

$a_{g}=$ Gravity of earth.

$\bar{h}=$ Average elevation at the start or end of each speed range in meters

$\bar{D}_{\text {start }}-\bar{D}_{\text {end }}=$ Distance travelled between start and end points in meters.

During the test, it was not possible to measure the track elevation. However, Track 9 is specially designed and build for coast down and drift/pull tests with near perfect flatness. Therefore, no grade effect included at the further calculations and the road load equation reduced as following.

$$
F=-M_{e} \cdot \frac{\bar{v}_{\text {start }}-\bar{v}_{\text {end }}}{\bar{t}_{\text {start }}-\bar{t}_{\text {end }}}
$$

Even the coast down test was performed at neutral gear, gears in the gearbox are still meshed and turning, there are some parasitic losses in the coast down data such as axle losses and transmission losses. Hence, to calculate the drag area, those parasitic losses must be excluded from coast down data. Axle efficiency test which is described in CFR Title 40, Part 1037.560, 2017 should be done to find the axle losses. However, this procedure need another axle which is separated from a vehicle. There was no available axle to perform axle efficiency test. Therefore, 
to calculate the axle losses, the default axle loss coefficients included in the US regulatory simulation tool, GEM, was used. Figure 4-3 presents the default axle spin loss as a function of speed. Power loss coefficients of an axle can be described by second order regression and using the regression coefficients axle spin losses can be found.

$$
\begin{gathered}
P_{\text {loss }}=c_{0}+c_{1} \cdot f_{\text {nwheel }}+c_{2} \cdot f_{\text {nwheel }}^{2} \\
F_{\text {spin }[\text { speed }]}=\frac{1}{\bar{v}_{\text {seg }[\text { speed }]}}\left[c_{0}+c_{1} \cdot \bar{v}_{\text {seg }[\text { speed }]} \cdot \operatorname{TRPM}+c_{2}\left(\bar{v}_{\text {seg }[\text { speed }]} \cdot T R P M\right)^{2}\right]
\end{gathered}
$$

Where:

$c_{0}, c_{1}, c_{2}=$ Regression coefficients coming from axle efficiency test.

$f_{\text {nwhe }}=$ Wheel speed in $\mathrm{rad} / \mathrm{s}$.

$\bar{v}_{\text {seg }[\text { speed }]}=$ The mean vehicle speed of high or low speed segments in $\mathrm{m} / \mathrm{s}$.

$T R P M=$ Tire revolutions per meter $[\mathrm{rpm} / \mathrm{m}]$. 


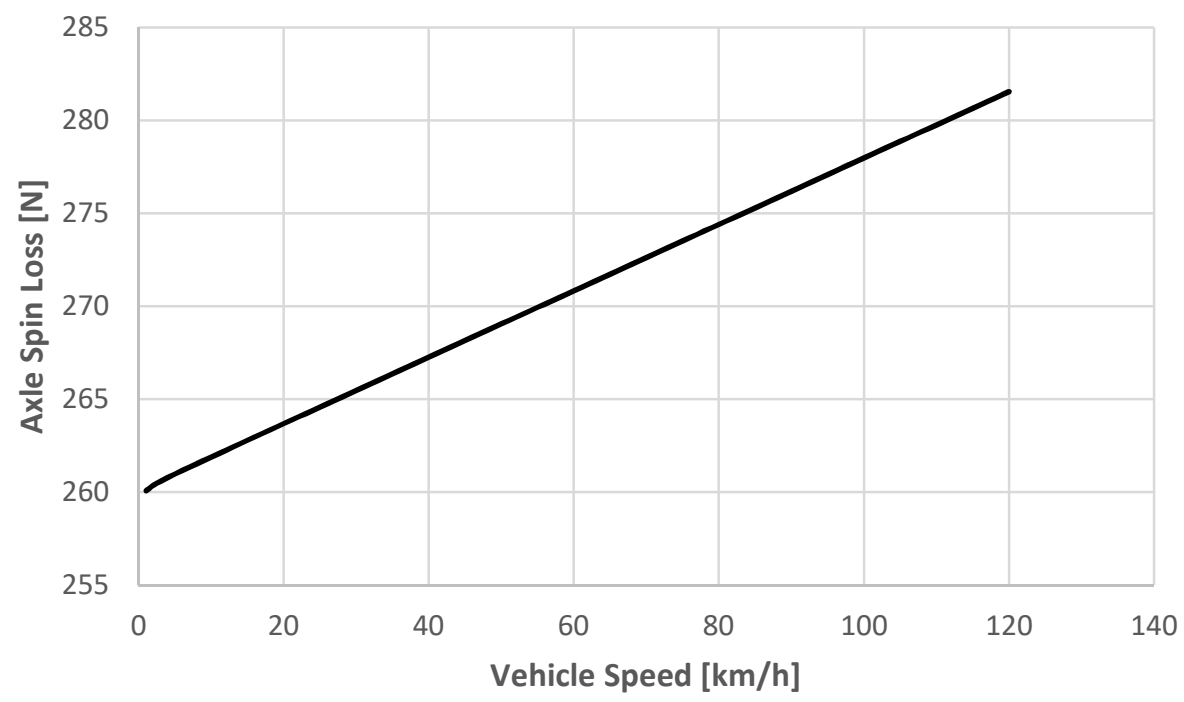

Figure 3-7: Graph of Default Axle Spin Loss as a Function of Speed

Axle speed losses calculated for high and low speed ranges and the difference between high and low speed ranges gives us $\Delta F_{\text {spin }}$.

Another loss which is captured by the coast down test but not relevant with drag area is the tire rolling resistance. For this reason, it must be subtracted from coast down data. In order to determine the tire rolling resistance coefficients, one of the drive axle tires was sent to Smithers Rapra North America's Ravenna Laboratory. Tire rolling resistance coefficients determined by the "Stepwise Coast Down Methodology for Measuring Tire Rolling Resistance" defined in the SAE J2452 standard. The result of the test provide the regression coefficients required to estimate the tire rolling resistance for different speeds. Tire rolling resistance can be calculated using the equation below. 


$$
F_{T R R}=n_{t} \cdot P^{\alpha} \cdot\left(\frac{L}{n_{t}}\right)^{\beta} \cdot\left(a+b \bar{v}+c \bar{v}^{2}\right)
$$

Where:

$n_{t}=$ number of tires at the axle.

$P=$ Inflation pressure of the tires in $\mathrm{kPa}$.

$L=$ Load over the axle in Newton.

$a, b, c=$ Tire rolling resistance regression coefficients.

$\alpha, \beta=$ Pressure and load coefficients.

Results of the rolling resistance test will be provided at Table 4-5 below. Results of the complete test will be provided at the appendix section.

Table 3-7: Results of Tire Rolling Resistance Test

\begin{tabular}{|c|c|c|c|c|}
\hline$\alpha$ & $\beta$ & $a$ & $b$ & $c$ \\
\hline-0.4398 & 1.0420 & 0.0498 & 0.00010871 & 0.00000085 \\
\hline
\end{tabular}

Tire rolling resistances were calculated for each speed segment (hi and low) and axles (steer, drive and trailer). The sum of the 3 axles gives the total rolling resistance for that speed segment.

$$
F_{T R R[\text { speed }]}=F_{T R R[\text { speed }], \text { steer }}+F_{T R R[\text { speed }], \text { drive }}+F_{T R R[\text { speed }], \text { trailer }}
$$


There were no data available for steer and trailer tires, so rolling resistance coefficients assumed as same with the drive tires for the calculations.

After finding rolling resistances for speed segments, ambient temperature correction was done by the following equation which is provided in the CFR.

$$
F_{T R R[\text { speed }], a d j}=F_{T R R[\text { speed }]} \cdot\left[1+0.006 .\left(24-\bar{T}_{a m b}\right)\right]
$$

Subsequently, it is possible to calculate drag area using the equation below.

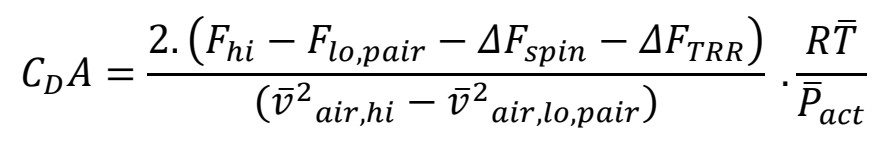

Where:

$F_{h i}=$ Road load force at high speed.

$F_{l o, p a i r}=$ The average of $F_{l o}$ values for a pair of opposite direction runs.

$\Delta F_{\text {spin }}=$ The difference in the drive axle spin loss force between high and low speed segments.

$\Delta F_{T R R}=$ The difference in TRR force between high and low speed segments.

$R=$ Specific gas constant $=287.058 \mathrm{~J} /(\mathrm{kg} \cdot \mathrm{K})$.

$\bar{T}=$ Mean air temperature in Kelvin.

$\bar{P}_{a c t}=$ Mean absolute air pressure in Pascal. 
Results of coast down tests and detailed comparison between CST and CD will be provided in Chapter 4. 


\section{RESULTS AND DISCUSSION}

\subsection{Drag Area Results}

VECTO software is a regulatory software which aims OEMs to perform tests and then post-process it with the software. It has two different modes; Engineering mode and declaration mode. In engineering mode user can change and define parameters such as validation criteria or vehicle parameters. However, declaration mode is quite strict and it does not allow the user to change some pre-defined validation criteria or vehicle parameters which were set by the authorities. All the post-processing in this study were performed with declaration mode. Results of VECTO- Air Drag is tabulated in Table 4-1.

Table 4-1Results of VECTO - Air Drag for Constant Speed Testing Method

\begin{tabular}{|l|c|}
\hline Average Ambient Temperature & $19.7^{\circ} \mathrm{C}$ \\
\hline Average Vehicle Speed (LS) & $14.1 \mathrm{~km} / \mathrm{h}$ \\
\hline Average Vehicle Speed (HS) & $89.1 \mathrm{~km} / \mathrm{h}$ \\
\hline Anemometer Misalignment & $-0.55^{\circ}$ \\
\hline$C_{D} A$ without Correction & $5.238 \mathrm{~m}^{2}$ \\
\hline Average Yaw Angle & $0.83^{\circ}$ \\
\hline$C_{D} A$ Cross Wind Correction & $-0.057 \mathrm{~m}^{2}$ \\
\hline$C_{D} A$ Correction for Anemometer & $-0.15 \mathrm{~m}^{2}$ \\
\hline$C_{D} A$ Measured & $5.031 \mathrm{~m}^{2}$ \\
\hline Vehicle Height & $4.06 \mathrm{~m}$ \\
\hline Frontal Area & $10.45 \mathrm{~m}^{2}$ \\
\hline Drag Coefficient $\left(C_{D}\right)$ & 0.481 \\
\hline Average Rolling Resistance Coefficient & $4.1948 \mathrm{~kg} / \mathrm{t}$ \\
\hline
\end{tabular}


For coast down post-processing, the procedure explained at section 3.4.2 was used and the results are provided for individual coast downs without any correction at Table 4-2 below.

Table 4-2: Results of Individual Coast Down Tests without Correction

\begin{tabular}{|c|l|c|c|c|c|c|c|}
\hline \multicolumn{2}{|c|}{ Test Number } & 1 & 2 & 3 & 4 & 5 & 6 \\
\hline \hline \multirow{3}{*}{$\begin{array}{c}\text { South } \\
\text { Heading }\end{array}$} & Drag Area $\left[m^{2}\right]$ & 4.686 & 4.605 & 4.679 & 4.507 & 4.609 & - \\
\cline { 2 - 8 } & Drag Coefficient [-] & 0.448 & 0.441 & 0.448 & 0.431 & 0.441 & - \\
\cline { 2 - 8 } & Average Yaw Angle [ $\left.{ }^{\circ}\right]$ & 0.44 & 0.90 & 0.19 & 0.72 & 0.10 & - \\
\hline \multirow{3}{*}{$\begin{array}{c}\text { North } \\
\text { Heading }\end{array}$} & Drag Area $\left[\mathrm{m}^{2}\right]$ & 4.636 & 4.605 & 4.431 & 4.478 & 4.753 & 4.656 \\
\cline { 2 - 8 } & Drag Coefficient [-] & 0.444 & 0.441 & 0.424 & 0.429 & 0.455 & 0.446 \\
\cline { 2 - 8 } & Average Yaw Angle [ $\left.{ }^{\circ}\right]$ & 0.65 & 0.30 & 0.10 & 0.27 & 0.82 & 1.23 \\
\hline
\end{tabular}

Median of the yaw angles was found as $0.64^{\circ}$. The validation criteria for yaw angle described as $\pm 1^{\circ}$ of the median yaw angle. Besides, validation criteria for drag area is \pm 2 standard deviations $(\sigma)$. Standard deviation of drag areas for all of the tests was found as $\sigma=0.0922$. Table 4-3 below show the upper and lower limits for yaw angle and drag area for the validation criteria described above.

Table 4-3: Upper and Lower Limits for Validation

\begin{tabular}{|c|c|c|c|}
\hline Parameter & Lower Limit & Average & Upper Limit \\
\hline Yaw Angle & $-0.36^{\circ}$ & $0.60^{\circ}$ & $1.64^{\circ}$ \\
\hline Drag Area & $4.420 \mathrm{~m}^{2}$ & $4.604 \mathrm{~m}^{2}$ & $4.79 \mathrm{~m}^{2}$ \\
\hline
\end{tabular}


As it can be seen at Table 4-3, all tests are within the validity criteria and no outlier elimination was needed. Average yaw angle and drag area after checking the validation criteria, was found as $0.60^{\circ}$ and $4.604 \mathrm{~m}^{2}$ respectively.

In order to be able to compare drag area results of US GHG Phase 2 with the results from its European counterpart, the drag area obtained from US GHG Phase 2 method needs to be corrected to zero yaw angle. Regression coefficients for correcting the yaw angle to zero for tractor and trailer combination obtained from European constant speed test procedure. Applying correction to the coast down results, drag area difference determined as $0.032 \mathrm{~m}^{2}$. After exclusion of the yaw angle effect from the drag area obtained from coast down method, corrected drag area and drag coefficient was found as $4.572 \mathrm{~m}^{2}$ and 0.438 respectively.

A direct comparison between the drag area results of constant speed test method (EU regulatory) and coast down method (US GHG Phase 2 regulatory) is tabulated in Table 4-4.

Table 4-4: Drag Area Comparison of Constant Speed and Coast Down Methods

\begin{tabular}{|c|c|c|c|c|}
\hline & \multicolumn{3}{|c|}{ Yaw Angle $\left[{ }^{\circ}\right]$} \\
\hline & & 0.83 & 0.60 & Corrected for 0 \\
\hline \multirow{2}{*}{$\begin{array}{c}\text { Drag Area } \\
\qquad\left(C_{D} A\right)\end{array}$} & $\begin{array}{c}\text { US GHG Phase } 2 \text { requirement, } \\
C D\end{array}$ & - & $4.604 \mathrm{~m}^{2}$ & $4.572 \mathrm{~m}^{2}$ \\
\hline & $\begin{array}{c}\text { EU Regulation requirement, } \\
C S T\end{array}$ & $5.088 \mathrm{~m}^{2}$ & - & $5.031 \mathrm{~m}^{2}$ \\
\hline & & \multicolumn{2}{|c|}{ Percent Difference } & $9.1 \%$ \\
\hline
\end{tabular}


As it can be seen at the Table 4-4 above, there is a $9.1 \%$ difference between the CST and $\mathrm{CD}$ results with respect to CST. In order to further investigate the reason of this difference, assumptions for each test method should be investigated.

Since constant speed test method measures torque directly from wheel hubs, all of the losses which are before the wheel hubs are not measured. This means that powertrain losses are not captured by CST method and there is no need to take them into account for post processing. Hence, torque measurement obtained by transducers contains only aerodynamic drag and tire

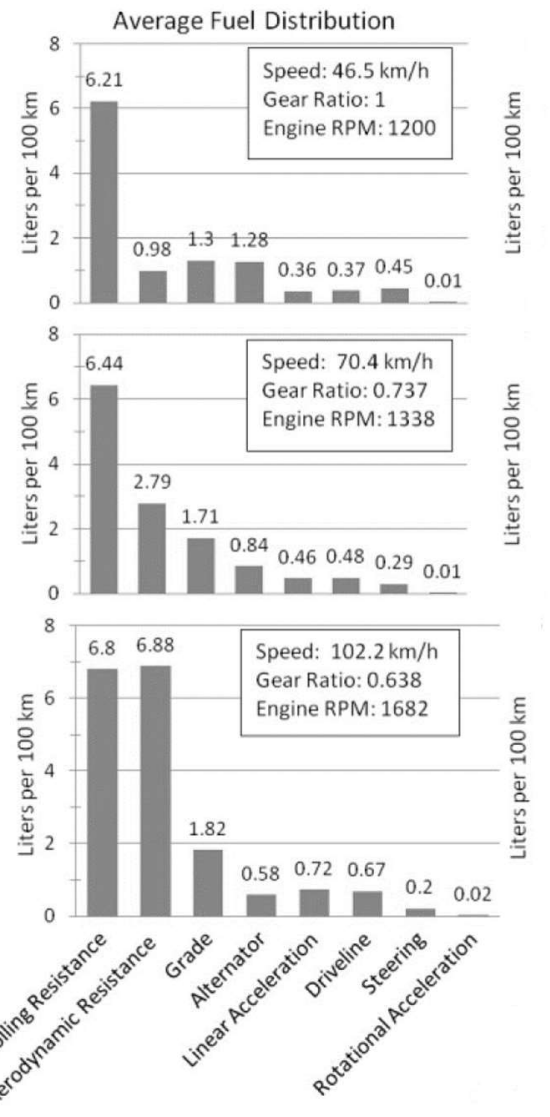
rolling resistance. However, because coast down test done by speed and time measurement, all parasitic losses are captured and therefore they need to be eliminated from the raw data. Yucel, S. et. al.[8] showed in his study that these parasitic losses are speed dependent. It means, efficiencies of these components are getting lower with increasing speed. Figure 4-1 shows the breakdown of fuel consumption of a heavy duty truck while it is cruising at three different steady speeds.

Figure 4-1: Average Fuel Consumption Breakdown of a Heavy Duty Truck for Three Different Steady Speeds (Adapted from: Yucel, S. et. al (2017)) 
Since the fuel consumption is directly related with the road load, it can be said that road load contribution of those attributes are speed dependent too. As it can be seen at the Figure 4-1, rolling resistance, aerodynamic resistance and driveline losses are dependent on the vehicle speed. Therefore, it is essential to subtract the low speed road load from the high speed road load.

Elimination methodology is clearly explained at CFR Title 40, Part 1037.528 as already discussed in section 3.4.2.4. After eliminations done, breakdown of road load force left is presented below.

Table 4-5: Breakdown of Road Load Contributions After Eliminations Done

\begin{tabular}{|c|c|c|c|c|c|c|c|}
\hline & 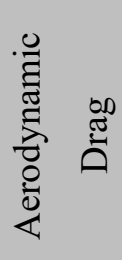 & 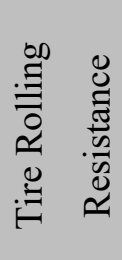 & 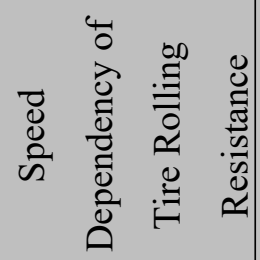 & $\begin{array}{l}0 \\
0 \\
0 \\
.0 \\
0 \\
0 \\
\frac{0}{x} \\
\frac{0}{x}\end{array}$ & 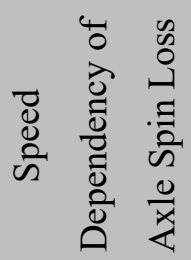 & 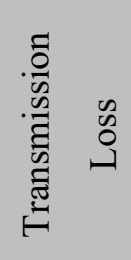 & 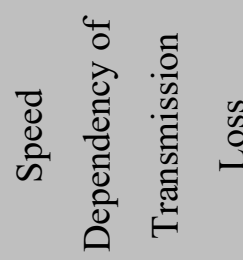 \\
\hline $\mathrm{CD}$ & $\checkmark$ & $\mathrm{X}$ & $\mathrm{X}$ & $\mathrm{x}$ & $\mathrm{x}$ & $\mathrm{x}$ & $\checkmark$ \\
\hline CST & $\checkmark$ & $\mathrm{X}$ & $\checkmark$ & \multicolumn{4}{|c|}{ Not Relevant } \\
\hline
\end{tabular}

As it can be seen at the Table 4-5, CST does not include the speed dependency of the tire rolling resistance while its counterpart $\mathrm{CD}$ method does not consider the speed dependency of transmission loss. However, Figure 4-1 show that the order of magnitude of tire rolling resistance is higher than driveline. Therefore, higher error can be expected for CST method. It could be one of the possible reasons of that $9.1 \%$ difference found between CST and CD methods. In order to further investigate this, CD test was post-processed again with the average low speed $(22.2 \mathrm{~km} / \mathrm{h})$ 
constant tire rolling resistance value calculated from the regression coefficient obtained from the stepwise rolling resistance test. At $22.2 \mathrm{~km} / \mathrm{h}$ rolling resistance was found as $4.2328 \mathrm{~kg} / \mathrm{ton}$. Furthermore, for low speed $(14.1 \mathrm{~km} / \mathrm{h})$ CST test tire rolling resistance calculated by using the stepwise test regression coefficients yields to $4.1080 \mathrm{~kg} / \mathrm{t}$ which is slightly lower than VECTO's estimation $(4.1948 \mathrm{~kg} / \mathrm{t})$. This show us even VECTO's estimation for tire rolling resistance is close to the actual one, constant tire resistance assumption approach causes the 9.1 percent difference from CD method.

By subtracting the speed dependency term from drag area equation 3.13, drag area was calculated again. This time the drag area difference reduced to 3.4 percent.

Table 4-6: Drag Area Results without TRR Speed Dependency

\begin{tabular}{|c|c|c|}
\hline & Drag Area & $\begin{array}{c}\text { Percent } \\
\text { Difference }\end{array}$ \\
\hline $\begin{array}{c}C_{R R}=4.2328 \mathrm{~kg} / \mathrm{t} \\
(\text { Constant TRR stepwise test })\end{array}$ & $5.100 \mathrm{~m}^{2}$ & $3.4 \%$ \\
\hline $\begin{array}{c}C_{R R}=4.1948 \mathrm{~kg} / \mathrm{t} \\
(\text { Constant VECTO result })\end{array}$ & $5.238 \mathrm{~m}^{2}$ & \\
\hline
\end{tabular}

As it can be seen in Table 4-6, not taking into account rolling resistance speed dependency reduced the difference from 9.1 percent to 3.4 percent. With this results it can be said that, constant tire rolling resistance assumption done by VECTO, results in an increased drag area. 


\subsection{Fuel Consumption Results}

This study was done as a part of a sponsored project. Therefore, timing of the project was a big concern. Moreover, during chassis dynamometer test, some technical problems related with dynamometer's balance in terms of flywheels, was experienced. Because of the timing concerns and technical problems, unfortunately it was not possible to test the exact drag coefficient values. However, it was possible to get some data for VECTO Long Haul Cycle. Time vs. speed and grade profile of VECTO Long Haul Cycle is presented at Figure 4-2 and individual test results presented at the Table 4-7.

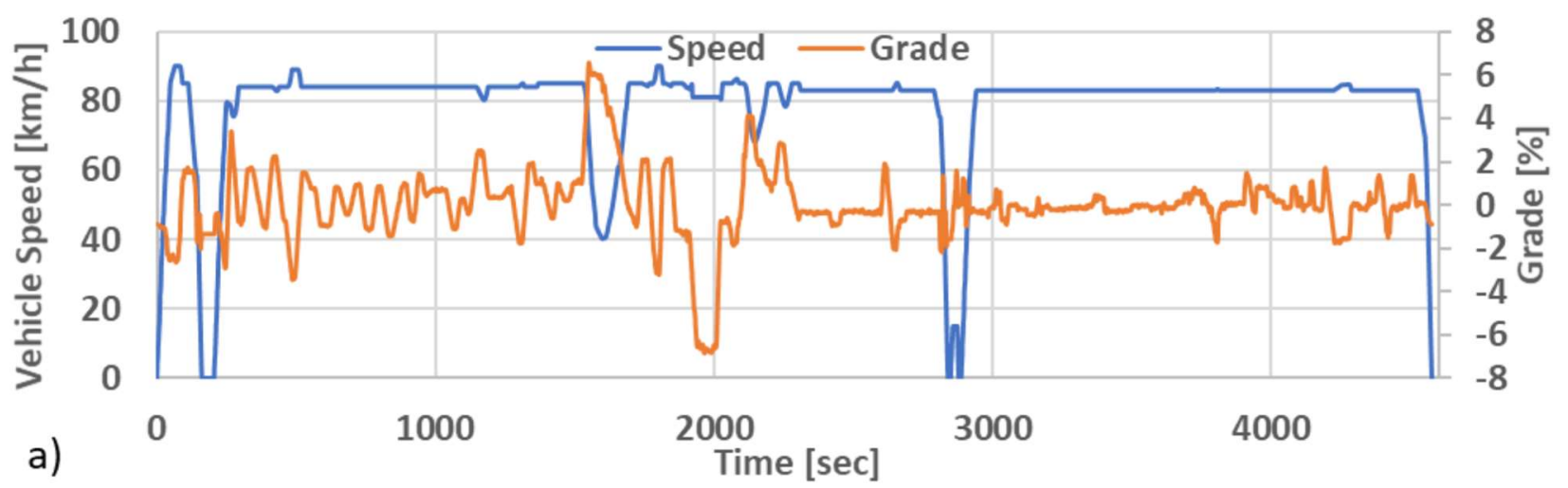

Figure 4-2: Time vs. Speed and Grade Profile of VECTO Long Haul Cycle

As it can be seen at Table 4.7, fuel consumption tests were performed for $C_{D}=0.484$, $\mu=5.3 \mathrm{~kg} / \mathrm{t}$ and $C_{D}=0.529, \mu=5.8 \mathrm{~kg} / t$ which results 8.5 percent difference in test drag areas and closest possible to the drag area difference found by the CD and CSTs. This setting resulted 2.7 percent difference on average ECU work done by the vehicle and this 2.7 percent 
difference resulted with 4.4 percent difference in average fuel consumption. It can be expected with equal rolling resistance coefficient settings for current drag coefficient setting, average ECU work and fuel consumption difference would be less than 2.7 percent and 4.4 percent.

Table 4-7: Fuel Consumption Results of VECTO Long Haul Cycle for Different Dyno Settings

\begin{tabular}{|c|c|c|c|c|}
\hline $\begin{array}{l}\text { Test Cycle and Test } \\
\text { Number }\end{array}$ & $\begin{array}{l}\text { VECTO Long } \\
\text { Haul } 1\end{array}$ & $\begin{array}{l}\text { VECTO Long } \\
\text { Haul } 2\end{array}$ & $\begin{array}{l}\text { VECTO Long } \\
\text { Haul } 3\end{array}$ & $\begin{array}{l}\text { VECTO Long } \\
\text { Haul } 4\end{array}$ \\
\hline Test Duration & 3586.9 & 3586.9 & 3586.9 & 3586.9 \\
\hline Dyno Setting & $\begin{array}{c}C_{D}=0.484 \\
\mu=5.3 \mathrm{~kg} / \mathrm{t}\end{array}$ & $\begin{array}{c}C_{D}=0.484 \\
\mu=5.3 \mathrm{~kg} / \mathrm{t}\end{array}$ & $\begin{array}{c}C_{D}=0.529 \\
\mu=5.8 \mathrm{~kg} / \mathrm{t}\end{array}$ & $\begin{array}{c}C_{D}=0.529 \\
\mu=5.8 \mathrm{~kg} / \mathrm{t}\end{array}$ \\
\hline $\begin{array}{l}\text { Simulated Weight } \\
{[\mathrm{lbs}]}\end{array}$ & 65000 & 65000 & 65000 & 65000 \\
\hline Test Distance [km] & 63.15 & 6.21 & 63.09 & 62.82 \\
\hline Average Speed $[\mathrm{km} / \mathrm{h}]$ & 63.38 & 63.44 & 63.31 & 63.04 \\
\hline ECU Work [kWh] & 90.52 & 89.91 & 93.34 & 93.08 \\
\hline $\begin{array}{l}\text { Fuel Consumption } \\
{[\mathrm{kg}]}\end{array}$ & 18.55 & 18.25 & 19.32 & 19.14 \\
\hline $\begin{array}{l}\text { Fuel Economy } \\
{[1 / 100 \mathrm{~km}]}\end{array}$ & 35.39 & 34.79 & 36.9 & 36.71 \\
\hline $\begin{array}{l}\text { Average Fuel } \\
\text { Consumption }[\mathrm{kg}]\end{array}$ & \multicolumn{2}{|c|}{18.40} & \multicolumn{2}{|c|}{19.25} \\
\hline $\begin{array}{l}\text { Percent Difference of } \\
\text { Average Fuel Cons. }\end{array}$ & \multicolumn{4}{|c|}{$4.4 \%$} \\
\hline
\end{tabular}




\section{CONCLUSION}

Until $2014 \mathrm{CO}_{2}$ emissions was not regulated for road vehicles. However, with the new coming regulations, authorities started to implement regulations for greenhouse gasses, especially $\mathrm{CO}_{2}$ and fuel consumption. $\mathrm{CO}_{2}$ is known one of the biggest contributors of greenhouse gasses, therefore climate change and global warming. Hence, $\mathrm{CO}_{2}$ emission regulations and control is very important.

Drag area is one of the most crucial parameter for $\mathrm{CO}_{2}$ emission regulation and fuel consumption. Thus, authorities both in US and Europe, defined new testing procedures to determine the drag area. However, they used different approaches and test procedures. While, US EPA following well known coast down procedure, European counterpart defined constant speed test.

In this study both methods investigated in same conditions with same test vehicle. Results showed that, different assumptions during post-processing can yield up to 9.1 percent difference in drag area. The most important difference between CST and CD test is the tire rolling resistance contribution to the road load. While, CD procedure is taking speed dependency of tire rolling resistance into account, CST methodology uses a constant tire rolling resistance value. This assumption, over estimating the drag area, because it counts the speed dependency of tire rolling resistance in the drag force.

Results showed that on VECTO Long Haul Cycle, 9.1 percent drag area difference with constant rolling resistance assumption of VECTO Air Drag Tool, would result a fuel consumption difference in the 
order of 2 to 3 percent. It can be expected even less fuel consumption difference by using speed dependent tire rolling resistance coefficient on CST. 


\section{BIBLIOGRAPHY}

[1] EU 2400/2017 (2017), Implementing Regulation (EC) No 595/2009 of European Parliement and of the Council as regards the determination of the $\mathrm{CO}_{2}$ emissions and fuel consumption of heavy-duty vehicels and amending Directive 2007/46/EC of the European Parliement and of the Council and Comission Regulation (EU) No 582/2011.

[2] Federal Register Part II Vol. 81, No. 206, (2016).

[3] N. Hall, "NASA, Forces Acting Drag," (2015). [Online]. Available: https://www.grc.nasa.gov/www/k-12/airplane/factord.html.

[4] “The Tyre Rolling Resistance Fuel Saving.”, (2003), Michelin

[5] H. Stenvall, "Chalmers Powertrain Coastdown," (2010), Chalmers University Of Technology.

[6] "Michigan Scientific Corporation high resolution Truck Torque Wheel System, Installation and Operation Manual.” (2014), Michigan Scientific Corporation.

[7] C.F.R., Title $40 \S 1037$, (2017) Office of the Federal Register National Archives.

[8] S. Yucel, M. M. Lucking, J. Magnuson, G. Paterlini, and B. Worel, (2017), “Time-Resolved Estimation of Fuel Consumption Breakdown of a Heavy Duty Truck Under Actual Road Conditions". 
[9] Barrand, J., Bokar, J., (2017), "Reducing Tire Rolling Resistance to Save Fuel and Lower Emissions".

[10] Rodriugez, F., et. al., (2019), “Heavy-Duty Aerodynamic Testing for CO2 Certification: A Methodology Comparison”.

[11] W. Mayer and J. Wiedemann, (2017), "Road Load Determination Based on Driving Torque Measurement".

[12] C. Paulina, D. Mcbryde, and M. Matthews, (2017), "Steady State Speeds Load Determinations Using Electric Vehicle Power or Dynamometer Measurements on Conventional Vehicles".

[13] V. A. Petrushov, (2017), "Coast Down Method in Time and Distance Variables for Tire Rolling Resistance Determination”.

[14] D. Savvidis, (2015), “Heavy Duty Vehicles' CO 2 Legislation in Europe and VECTO Simulation Tool".

[15] J. Howell, C. Sherwin, and G. Le Good, (2017), "SAE TECHNICAL Aerodynamic Drag of a Compact SUV as Measured On-Road and in the Wind Tunnel” no. 724.

[16] Mock, P., (2016), "Vehicle Emissions Testing in the European Union”.

[17] R. Ahlawat, J. Bredenbeck, and T. Ichige, (2013), "Estimation of Road Load Parameters via On-road Vehicle Testing Energy Loss in Vehicles”. 
[18] B. Demirgok, (2018), Development of an Emissions Monitoring Methodology Using OnBoard NOx Sensors and Revision to Current In-Use Emissions Regulatory Protocols.

[19] M. C. Besch, (2016), In-line, Real-time Particulate Matter Sensors for OBD and Exhaust After-treatment System Control Applications.

[20] A. Thiruvengadam, (2008), Evaluation of Exhaust After-Treatment Device Effectiveness in Reducing Regulated and Unregulated Emissions from Natural Gas Fueled Heavy Duty Transit Bus. 